This item was submitted to Loughborough's Research Repository by the author.

Items in Figshare are protected by copyright, with all rights reserved, unless otherwise indicated.

\title{
Expansion of human mesenchymal stem cells on microcarriers
}

PLEASE CITE THE PUBLISHED VERSION

http://www.springerlink.com/content/57t4lj6553956p07/

\section{PUBLISHER}

(c) Springer Verlag

\section{VERSION}

AM (Accepted Manuscript)

\section{LICENCE}

CC BY-NC-ND 4.0

\section{REPOSITORY RECORD}

Hewitt, Christopher J., Kenneth Lee, Alvin W. Nienow, Robert James Thomas, M. Smith, and Colin R. Thomas. 2011. "Expansion of Human Mesenchymal Stem Cells on Microcarriers". figshare. https://hdl.handle.net/2134/9184. 
This item was submitted to Loughborough's Institutional Repository (https://dspace.lboro.ac.uk/) by the author and is made available under the following Creative Commons Licence conditions.

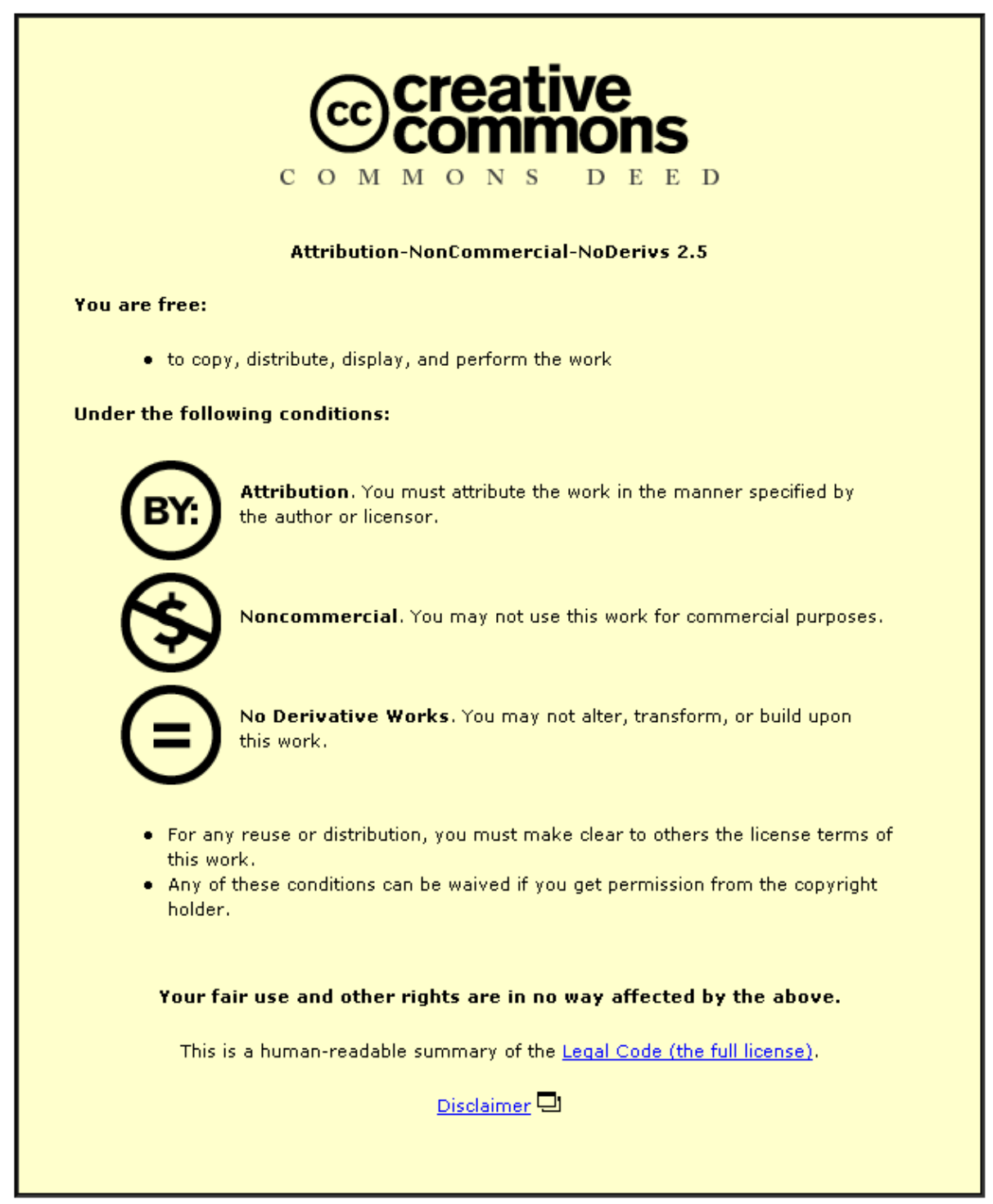

For the full text of this licence, please go to: http://creativecommons.org/licenses/by-nc-nd/2.5/ 


\section{Expansion of human mesenchymal stem cells on microcarriers}

Christopher J. Hewitt ${ }^{1 *}$, Ken Lee ${ }^{1,2}$, Alvin W. Nienow ${ }^{1,2}$, Robert J. Thomas ${ }^{1}$, Mark Smith ${ }^{3+}$ and Colin R. Thomas ${ }^{2}$

${ }^{1}$ Centre for Biological Engineering, Department of Chemical Engineering, Loughborough University, Leicestershire, LE11 3TU, United Kingdom.

${ }^{2}$ School of Chemical Engineering, University of Birmingham, Edgbaston, Birmingham, B15 2TT, United Kingdom.

${ }^{3}$ Smith and Nephew, York Science Park, Heslington, York, YO10 5DF, UK.

*Author for correspondence. (Fax: +44-121-414-5324; E-mail: c.j.hewitt@lboro.ac.uk)

${ }^{+}$Current address, AedStem Ltd, BioCentre, Heslington, York Science Park, YO10 5DG, UK.

Keywords: human mesenchymal stem cells; microcarriers; regenerative medicine bioprocessing; spinner flasks 


\begin{abstract}
The effects on human mesenchymal stem cell growth of choosing either of two spinner flask impeller geometries, two microcarrier concentrations and two cell concentrations (seeding densities) were investigated. It was found that Cytodex 3 microcarriers were not damaged when held at the minimum speed for their suspension, $\mathrm{N}_{\mathrm{JS}}$, using either impeller, nor was there any observable damage to the cells. The maximum cell density was achieved after 8 to 10 days of culture with up to a 20 fold expansion in terms of cells per microcarrier. An increase in microcarrier concentration or seeding density generally had a deleterious or neutral effect, as previously observed for human fibroblast cultures. The choice of impeller was significant, as was incorporation of a 1 day delay before agitation to allow initial attachment of cells. The best conditions for cell expansion on the microcarriers in the flasks were 3000 microcarriers $\mathrm{mL}^{-1}$ (ca. 1 g dry weight $\mathrm{L}^{-1}$ ), a seeding density of 5 cells per microcarrier with a 1 day delay before agitation began at $\mathrm{N}_{\mathrm{JS}}(30 \mathrm{rpm})$, using a horizontally suspended flea impeller with an added vertical paddle. These findings were interpreted using Kolmogorov's theory of isotropic turbulence.
\end{abstract}

\title{
Introduction
}

The next healthcare revolution will apply regenerative medicines, creating biological therapies or substitutes for the replacement or restoration of tissue function lost through failure or disease. However, whilst science has revealed the potential of such therapies, and early products have shown their power (Barker et al. 2011), there is now a need for the long term supply of human mesenchymal stem cells (hMSCs) in sufficient numbers to create reproducible and cost effective therapeutic products. Since human cells are known to develop both genetic and epigenetic instability over many passages, as well as loss of functionality (Allegrucci and Young 2007), there is a definite need for technologies that will allow the maximal expansion of each cell line for cryobanking at low passage numbers for larger scale healthcare applications. For scale-up of 
comparable mammalian cell systems where attachment is essential, microcarriers are used in bioreactors to provide a large surface area per unit volume of bioreactor (Nienow 2006). However, even for mammalian cells, little work has been done to study the impact of the fluid dynamic conditions on bioreactor performance because quite early in the development of that technology, free suspension culture became available and quickly dominated because it is easier to perform (Schut et al. 1997; Nienow 2006; Kumar at al. 2008). Thus whilst microcarriers have been shown to be appropriate for human embryonic and mesenchymal stem cells (Abranches et al. 2007; Frauenschuh et al. 2007; Oh et al. 2009), little detailed work has been done on them to optimise cell microcarrier attachment protocols or cell proliferation and growth. Importantly, human stem cells can't automatically be considered to behave in a similar way to other adherent cells lines. This is because with human stem cells it is the cell itself that forms the basis of the therapeutic product and not the proteins that they produce. That is, the cell itself may end up being integrated into the body and therefore cannot be harmful to the patient in any way. Therefore we do not have the luxury of selecting amenable cell lines for bioprocessing i.e. what is derived from human tissue has to stay exactly the same throughout the entire process from expansion, through purification to formulation and finally delivery. It is also known that all animal cells used for the production of therapeutic proteins have accumulated many genetic abnormalities that make them tumourigenic and hence more suitable to longer term culture (Thomson 2007). This cannot be so for human stem cell lines; obviously they cannot be tumourigenic so they are not immortal and are therefore much more sensitive to culture conditions than more conventional animal cell lines. Indeed even minor variations in the processing conditions have been shown to cause major variations in cultured human stem cells such as different lineage commitments and genetic stability issues (Allegrucci and Young 2007). The process environment therefore needs to be fully understood in order to develop a high level expansion strategy to prevent effects on safety and efficacy. 
Clearly, for a microcarrier's entire surface to be available for cell attachment and growth, microcarriers need to be fully suspended in the growth medium. This condition can be achieved by mechanical agitation (Nienow 1997a), which also homogenises the environment with respect to substrate composition and temperature whilst facilitating oxygen transfer to the cells and, as importantly, $\mathrm{CO}_{2}$ stripping from the media (Nienow 2006). However, increased agitation might cause damage to the microcarriers or cells, as found under some conditions for human fibroblasts (Hu et al. 1985; Croughan et al. 1988, 1989) and bovine embryonic kidney cells (Cherry and Papoutsakis 1988). None of these issues have been thoroughly studied or resolved for microcarrier cultures of hMSCs.

Most literature addressing damage to particles of a similar size to microcarriers $(100-300 \mu \mathrm{m})$ has been from the perspective of crystallisation/abrasion. Studies have shown that particle damage is mostly related to particle-impeller and particle-particle collisions. In either case, damage increases with increasing particle size, with increasing particle concentration and with increasing agitation intensity (Nienow 1997b). Other work has shown that freely suspended mammalian cells (size 15 to $20 \mu \mathrm{m}$ ) are much less sensitive to fluid dynamic stresses induced by agitation or sparged aeration than originally thought (indeed the impact of bursting bubble effects can be largely discounted if Pluronic F68 is included in the culture medium (Oh et al. 1992)). However, those growing on microcarriers appear to be more sensitive, probably because they are attached to relatively large particles that are more prone to collisions, which might damage the cells (Nienow 1997b). For fibroblasts, cell damage in these circumstances has been related to the relative size of the microcarriers and the Kolmogorov microscale of turbulence (Croughan et al. 1987). Damage became significant when the microscale was about two-thirds the size of the microcarriers, or smaller (Croughan et al. 1987). In addition to these considerations, it is also important to ensure that cells are attached to the microcarriers efficiently and a priori it is not obvious how this should 
be done. Clearly, if the microcarriers in the bioreactor are not suspended during attachment, the cells will tend to attach only to the upper surface of the microcarriers. Furthermore, even if there is sufficient agitation to cause suspension and even possibly increased cell-microcarrier contacts under the action of turbulence, attachment may not occur effectively if the time of contact is too short or the turbulence too great.

In this work, these phenomenon were investigated using hMSCs isolated from placental tissue in $250 \mathrm{~mL}$ spinner flasks with two impeller geometries and a well-known commercially available microcarrier, Cytodex 3 (GE Healthcare, Sweden) shown to be suitable for the expansion of both murine embryonic and mesenchymal stem cells (Abranches et al. 2006; Frauenschuh et al. 2007). The effects on cell expansion of impeller geometry, seeding density and microcarrier concentration were investigated. For each geometry, the minimum agitation speed for microcarrier suspension, $\mathrm{N}_{\mathrm{JS}}$, was used, to ensure the microcarrier surfaces were available whilst minimising possible agitation damage. In each case, the effect of introducing a delay in starting agitation was investigated. During such a delay, cell attachment might occur.

\section{Methods and Materials}

\section{Cell growth and conditions}

hMSCs were isolated from placental tissue and donated by Smith \& Nephew (York, UK). Cells were cryopreserved in growth medium supplemented with $10 \%$ dimethyl sulphoxide at passage five (at least $8.75 \times 10^{5}$ cells $\mathrm{mL}^{-1}$ ) and all microcarrier experiments were performed at passage nine. Cells were cultured in tissue culture medium composed of Dulbecco's Modified Eagles Medium (low glucose - DMEM; Sigma, UK) supplemented with 10\% Dulbecco's Modified Eagles Medium/Hams F12 premix (Sigma, UK), 2 mM L-glutamine (Sigma, UK), 1\% non- 
essential amino acids (Sigma, UK) and $50 \mathrm{IU} \mathrm{mL}^{-1}$ penicillin and $50 \mu \mathrm{g} \mathrm{mL}^{-1}$ streptomycin (Sigma, UK). Foetal bovine serum (Mycoplex ${ }^{\mathrm{TM}}$ EU FBS; PAA, Austria) was supplemented at a concentration of $20 \%(\mathrm{v} / \mathrm{v})$. Inoculum for spinner flasks was prepared using static monolayer growth in $175 \mathrm{~cm}^{2}$ tissue culture flasks (T175). Cells were thawed and seeded from cryopreserved stocks at a concentration of $5 \times 10^{3}$ cells $\mathrm{cm}^{-2}$ (i.e. $8.75 \times 10^{5}$ cells $\mathrm{mL}^{-1}$ ) to tissue culture flasks and incubated at $37^{\circ} \mathrm{C}$ under a humidified $5 \% \mathrm{CO}_{2}$ atmosphere. Medium was used at a ratio of $0.3 \mathrm{~mL}$ $\mathrm{cm}^{-2}$, and was replaced every 2 days of culture. Once confluence was reached cells were removed as set out below from the culture surface and reseeded to the required cell density in spinner flasks. For such a passage, flasks were washed twice with $\mathrm{Ca}^{2+}$ and $\mathrm{Mg}^{2+}$ free $\mathrm{PBS}$ and then incubated for five minutes in trypsin-EDTA solution $(0.5 \mathrm{~g}$ trypsin and $0.2 \mathrm{~g}$ EDTA per litre of PBS; Sigma, UK) until complete cell removal. The trypsin was then inactivated by the addition of fresh tissue culture medium to the detached cell suspension. The amount of medium added was equivalent to three times the volume of the trypsin solution used for cell detachment. The cell suspension was then centrifuged at $220 \mathrm{~g}$ for $5 \mathrm{~min}$, the supernatant discarded and the remaining pellet re-suspended in an appropriate volume of tissue culture medium in a spinner flask.

Cytodex-3 (GE Healthcare, Sweden), a solid microcarrier $175 \mu \mathrm{m}$ in mean $\left(\mathrm{d}_{50}\right)$ diameter with a collagen surface over a dextran matrix, was used in all cases. Microcarriers were prepared for use according to the manufacturer's instructions except where stated. Briefly, dry microcarriers were hydrated prior to use in $\mathrm{Ca}^{2+}$ and $\mathrm{Mg}^{2+}$ free PBS (50 $\mathrm{mL} \mathrm{g}^{-1}$ dry weight) overnight at $37^{\circ} \mathrm{C}$. Microcarriers were autoclaved to remove trapped gas and then rinsed twice with PBS and reautoclaved. Microcarriers were then washed with culture medium and transferred to the spinner flask. Flasks were then placed into a $37^{\circ} \mathrm{C}, 5 \% \mathrm{CO}_{2}$ incubator and stirred gently $(30 \mathrm{rpm})$ for 30 min to allow for gaseous and temperature equilibration prior to inoculation. Because of swelling 
during rehydration, the final mean microcarrier diameter was calculated to be ca. $210 \mu \mathrm{m}$, assuming a swelling factor of $15 \mathrm{~mL} \mathrm{~g}^{-1}$ dry weight (GE Healthcare 2009).

All microcarrier cultures were performed using Sigmacote (Sigma, UK) treated $250 \mathrm{~mL}$ spinner flasks (BellCo, New Jersey, USA) with a working volume of between 80 and $100 \mathrm{~mL}$. Two impeller geometries were used (Figure 1) throughout: the first (G1) consisted only of a magnetically driven horizontally suspended flea (length, $D=45 \mathrm{~mm}$; diameter, $d=10 \mathrm{~mm}$ ), whilst the second (G2) was made from the same suspended flea with an additional vertical Teflon paddle (30 mm high; length, $D=55 \mathrm{~mm}$ ). Agitation was via a magnetic stirrer platform (BellCo, New Jersey, USA). Cultures were incubated at $37^{\circ} \mathrm{C}$ in a $5 \% \mathrm{CO}_{2}$ enriched atmosphere. $\mathrm{pH}$ was maintained between $7-6.5$ (by colourimetric visualisation). Seeding densities and microcarrier concentrations were varied as were impeller geometry and speed.

\section{Other Analytical Techniques}

Cell concentrations in T175 flasks were determined by counting replicate samples on an improved Neubauer haemocytometer (Butler 1996) under a phase contrast microscope (Nikon, Japan; 100× magnification). Additionally, viability was determined by the trypan blue exclusion method. For nuclei counts of microcarrier attached cells, samples were incubated in culture medium with 5\% (v/v) dextranase (Sigma, UK) for $15 \mathrm{~min}$ to dissolve the microcarriers. Samples were then centrifuged at $1000 \mathrm{rpm}$ for $15 \mathrm{~min}$ and the supernatant discarded. The cell pellet was then resuspended in a staining solution equal to $50 \%$ the original volume, comprised of $0.1 \% \mathrm{w} / \mathrm{v}$ crystal violet (Sigma, UK) and $0.1 \% \mathrm{v} / \mathrm{v}$ Triton X-100 (Sigma, UK), in $0.1 \mathrm{M}$ citric acid and incubated for $2 \mathrm{~h}$. The number of nuclei was then counted on an improved Neubauer haemocytometer as above. Microcarrier size analysis was performed using a Malvern Mastersizer (Malvern, UK). 


\section{Results and Discussion}

Two impeller geometries G1 and G2 were chosen for this work (Figure 1) because both are used in commercially available spinner flasks and are commonly found in the literature on stem cell culture. In all experiments, the spinner flasks were agitated at the minimum speed for microcarrier suspension, $\mathrm{N}_{\mathrm{JS}}$. $\mathrm{N}_{\mathrm{JS}}$ is the impeller speed at which the microcarriers are 'just fully suspended'. Operation at this speed does not necessarily mean that the microcarriers are homogenously dispersed throughout the liquid medium (Ibrahim and Nienow 2004). $\mathrm{N}_{\mathrm{JS}}$ was found experimentally by visual observation, which is the most common way to assign this suspension condition (Nienow 1997a) to be $50 \mathrm{rpm}$ and $30 \mathrm{rpm}$ for G1 and G2 respectively. The Reynolds numbers, Re, at these conditions were about 1700 and 1500 respectively, which compare well with other spinner flask studies with microcarriers (Table 1$).\left(\operatorname{Re}=N D^{2} / v\right.$ where $N$ is the agitator speed (revolutions per second, rps), $D$ the agitator diameter $(\mathrm{m})$ and $v$ is the kinematic viscosity of the medium $\left(\mathrm{m}^{2} \mathrm{~s}^{-1}\right) . D$ was taken to be the length of the spinner bar for $\mathrm{G} 1$ and of the vertical paddle for $\mathrm{G} 2$ and $\mathrm{v}$ was assumed to be the kinematic viscosity of water, $10^{-6} \mathrm{~m}^{2} \mathrm{~s}^{-1}$.)

Modern analysis of the impact of stresses generated by agitation on animal and bacterial cells is usually based on Kolmogorov's theory of isotropic turbulence (Thomas and Zhang 1998; Nienow, 2006). This theory requires the flow in the vessel to be highly turbulent for it to be applicable. Since at least 1950 this condition has been generally considered to require $\operatorname{Re}>\sim 10^{4}$ (Rushton et al. 1950) and it is still defined that way today (Paul et al. 2004). Under these conditions, the microscale of turbulence, $\lambda_{K}(\mathrm{~m})$ can be determined from

$$
\lambda_{K}=\left(v^{3} / \varepsilon_{T}\right)^{1 / 4} \quad 1
$$

where $\varepsilon_{T}$ is the local specific energy dissipation rate $\left(\mathrm{W} \mathrm{kg}^{-1}\right)$. It is then commonly postulated that if the size of the biological entity is $<\lambda_{K}$, damage will not occur. The minimum value of $\lambda_{K}$ in the 
vessel can be obtained from $\left(\varepsilon_{T}\right)_{\max }$, which is in the region close to the impeller, and the ratio $\left(\varepsilon_{T}\right)_{\max } / \bar{\varepsilon}_{T}$ where $\bar{\varepsilon}_{T}$ is the mean specific energy dissipation rate given by

$$
\bar{\varepsilon}_{T}=P o N^{3} D^{5} / V
$$

where $V$ is the volume of media in the vessel $\left(\mathrm{m}^{3}\right)$. Both Po, the impeller power number (dimensionless), and $\left(\varepsilon_{T}\right)_{\max } / \bar{\varepsilon}_{T}$ depend on the particular impeller/vessel configuration (Nienow 2010).

Here, $\operatorname{Re}<10^{4}$ so that the flow is in the transition region of Reynolds numbers. It is certainly not fully turbulent or "completely turbulent" as suggested by Sucosky et al. (2004). A more reasonable expression might be "moderately turbulent" (Venkat et al. 1996). Thus, there are a number of difficulties in addressing the problem via turbulence theory. Nevertheless, Croughan et al. (1987) developed a turbulence-based model of the potential for damage based on the suggestion of Nagata (1975) that the flow became turbulent at $\operatorname{Re}>10^{3}$. Subsequently, others have followed that approach. In order to compare this and earlier work, and because an alternative is not available, this approach was also followed here. It is certainly not appropriate to treat the flow is if it were laminar.

In order to estimate the minimum Kolmogorov microscale of turbulence, values are required for Po and $\left(\varepsilon_{T}\right)_{\max } / \bar{\varepsilon}_{T}$. Po will change with impeller speed as the flow is not fully turbulent and the tank is not baffled; and a measured value is not available for the impeller shapes in the spinner vessel. Following Cherry and Papoutsakis (1986), a power number of 0.5 was assumed for the spinner bar in unbaffled conditions in G1, which is not unreasonable as its shape approximates a 2-blade paddle. Such 2-bladed paddles in unbaffled tanks have rarely been studied but in a report by Nagata (1975), none of a wide range of geometries gave a power number $>1$ for the Re values used in this work. As one would expect spinner bars of circular cross section give rise to less drag 
than flat blades, so the power number assumption made here seems reasonable. The shape of G2, which also has a vertical paddle of significant cross-sectional area above the spinner bar, suggests a higher value and a power number of 1 has been assumed. Finally, since $\left(\varepsilon_{T}\right)_{\max } / \bar{\varepsilon}_{T}$ is also unknown, it was estimated by the long-standing recommendation (Davies, 1985), which is still considered appropriate (Kresta and Brodkey 2004), that all the energy dissipation occurs in the impeller zone, of volume equal to the impeller swept volume. The calculations for these assumptions are shown in Table 2 giving estimated microscales, $\lambda_{K}$ of ca. 130 and $185 \mu \mathrm{m}$ for G1 and $\mathrm{G} 2$ respectively, assuming water-like fluid properties for the media. These values are fairly insensitive to power number; for example, an increase of 2 in power number would only change the estimated microscale by factor of about 1.2.

Both 130 and $185 \mu \mathrm{m}$ are between the mean diameter of the (swollen) microcarriers and half of that diameter, the latter shown by Croughan et al. (1987) as the value at which damage to fibroblasts became severe. It is therefore feasible that damage to cells may have occurred because of the turbulence. Relatively low power numbers, as assumed here, are conservative in that higher values would give even lower microscale values, although the effect would be small, as mentioned earlier.

In order to investigate whether the agitation intensity required to suspend microcarriers damaged them, either due to turbulence or microcarrier-microcarrier collisions (Nienow and Conti 1978; Cherry and Papoutsakis 1986; Croughan et al. 1987), experiments with 3000 Cytodex 3 microcarriers $\mathrm{mL}^{-1}$ in fresh medium were performed. This concentration of Cytodex microcarriers was chosen because their total surface area in the spinner flasks approximately matched the available surface area in a standard T175 flask. It represents about $1 \mathrm{~g}$ dry weight $\mathrm{L}^{-1}$, assuming 3 $\times 10^{6}$ microcarriers (g dry weight $)^{-1}$ (GE Healthcare 2009). For fibroblast cultures, this was close 
to the concentration that gave the optimum average specific growth rate (Croughan et al. 1988). The contents of the spinner flask were held at $\mathrm{N}_{\mathrm{JS}}$, in this case $50 \mathrm{rpm}(\mathrm{G} 1)$ and at $37^{\circ} \mathrm{C}$ for 7 days in a humidified incubator. At discrete time points, microcarriers were sampled and the particle size distribution measured. It can be seen (Figure 2) that there was no measureable change in particle size distribution after 3 and 7 days agitation at $\mathrm{N}_{\mathrm{JS}}$. Microscopic observation revealed no changes in the morphology of the microcarriers nor did they show any observable signs of stress, such as lines or fractures on their surfaces. It can therefore be concluded that the Cytodex 3 microcarriers are not damaged under the fluid dynamic conditions even if collisions were occurring.

In order to investigate the effects of the impeller geometry, microcarrier concentration, seeding density and agitation delay on cell growth, a series of duplicate experiments was carried out. For all experiments, reproducible results were obtained (Table 3). The maximum cell density always occurred between 8-10 d of culture and thereafter a decrease in cell concentration occurred. An example is given in Figures 3 and 4 (G1 impeller at 50 rpm, 3000 microcarriers $\mathrm{mL}^{-1}$, seeding density 5 cells/microcarrier with a 1 day impeller delay). The lower seeding density of the cells was chosen because it mirrored that used in standard T175 culture and indeed cultures were found not to grow below this concentration and this therefore represents the minimum seeding density for successful hMSC culture. This behaviour and minimum value is similar to that observed for FS-4 fibroblast cultures (Hu et al. 1985). For FS-4 fibroblasts a 4 fold increase in cells per bead was considered "good" (Croughan et al. 1988) and here increases up to 20 fold were obtained.

Microscopical examination of the microcarriers during the culture was very interesting (Figure 4). It would seem that during the unagitated conditions of day 1 that cells did not attach to the microcarriers uniformly i.e. some microcarriers had more cells than others and some had no cells 
at all. Further examination of microcarriers on days $2-9$ showed a decrease in the number of microcarriers with no cells attached. This confirms the suggestion that during the agitated conditions, cells are able to detach and transfer between microcarriers either directly or when microcarriers collide and periodically aggregate (Cherry and Papoutasakis 1988). Such aggregates under the agitation conditions experienced here were relatively short lived. After 9 days, cell nuclei counts per microcarrier began to decrease as cells died and detached from the surface of the microcarrier, presumably in response to a detrimental change in the culture conditions. In all cases, viable cells retained their fibroblast-like morphology, an essential characteristic for maintenance of cell phenotype as there are no measureable and universally accepted set of surface expressed markers for this hMSC cell line. At the times of maximum numbers of cells per microcarrier, the values of cells per unit area were of the order of $10^{4}$ to $10^{5}$ cells $\mathrm{cm}^{-2}$, similar to those obtained in a standard T175 culture $\left(10^{5}\right.$ cells $\left.\mathrm{cm}^{-2}\right)$.

When the initial microcarrier concentration was increased from 3000 to 7500 microcarriers $\mathrm{mL}^{-1}$ (i.e. more surface area for growth), the effect on the maximum number of cells per microcarrier was generally deleterious or neutral, as can be seen from the expansion factors in Table 2 . In terms of maximum cells per mL, there was an increase with microcarrier concentration but usually much less than the 2.5 fold increase that would be implied by the increased surface area. For FS- 4 fibroblasts, Croughan et al. (1988) and Hu et al. (1985) also observed adverse effects of increased microcarrier concentrations, in longer lags, decreased growth rates and decreased "multiplication ratios" (expansion factors). It might be expected that with an increase in the number of microcarriers $\mathrm{mL}^{-1}$ that there should be an increase in the number of collisions proportional to the square of the concentration (Nienow and Conti 1978), with possibly concomitant associated cell death. Although this argument is considered the most likely reason for the observations, it must be noted that significant numbers of dead cells or cell debris were not seen in free suspension, even 
at the higher microcarrier concentration. Their absence may be significant because dead or dying cells spontaneously detach from the microcarrier surface. It might be speculated as an alternative that collisions do not kill cells directly but rather reduce cell growth and/or division. This requires further investigation. Meanwhile it would seem satisfactory to use 3000 microcarriers $\mathrm{mL}^{-1}$ in spinner flasks for the expansion of hMSCs.

When the seeding density was doubled from 5 to 10 cells per microcarrier, the effect on the maximum number of cells per microcarrier was again generally deleterious or neutral, with the exception of one observation at 3000 microcarriers $\mathrm{mL}^{-1}$ and 10 cells/microcarrier for impeller G1 (Table 2). For a similar observation with FS-4 fibroblasts, Croughan et al. (1988) suggested an effect of growth inhibiting factors but there seems little or no independent evidence for this. As a seeding density of 5 cells per microcarrier was required for any growth, it is suggested that this should be the preferred level for spinner flask expansion of hMSCs.

With respect to mean maximum cell number per microcarrier and expansion factor, growth with the G2 impeller was found to be better than with the G1 impeller. This difference might be because the estimated minimum microscale of turbulence was not only higher for the former but was larger than two-thirds of the microcarrier diameter. Data in Croughan et al. (1987) for FS-4 fibroblasts also suggests that $\lambda_{K} \geq \sim 2 / 3$ may be a criterion for the agitation conditions under which damage would not be expected. However, as noted earlier, microscopical examination did not reveal any significant numbers of dead cells in suspension. Their absence is significant because dead or dying cells spontaneously detach from the microcarrier surface. It is possible that the bulk mixing or the level of gas-liquid mass transfer through the upper surface of the media may have also been better because of the upper vertical paddle. The lack of appropriate instrumentation means this suggestion cannot be confirmed. Further investigation is needed to 
resolve these issues. Nevertheless, the choice of spinner impeller is of significance and it is recommended that an impeller is chosen that gives a value of the Kolmogorov microscale of turbulence close to or greater than the bead diameter (at the minimum suspension speed).

When an impeller delay of 1 day was introduced the effect on maximum cell number was generally markedly positive on mean maximum cell numbers per microcarrier, although in a few cases there was no significant change. The positive effect was more pronounced at the lower microcarrier concentration of 3000 microcarriers $\mathrm{mL}^{-1}$. This effect is most likely to be because a delay in agitation allows the cells to attach properly to the microcarriers. Microscopic observations suggest that the majority of cells required at least $2 \mathrm{~h}$ to attach, with an additional period of $2 \mathrm{~h}$ needed to ensure maximum attachment. Further observations in both monolayer and microcarrier culture indicated that cells needed at least $24 \mathrm{~h}$ to allow cell 'spreading', which ensures future cell division and growth.

In passing, it is perhaps worth noting that a small increase in kinematic viscosity $v$ would lead to a significant increase in $\lambda_{K}$, which should lead to a reduction of cell damage. However, that action also leads to a significant reduction of Re, e. g., a doubling of $v$ reduces $\operatorname{Re}$ by a factor of 2 , so that application of Kolmogorov's theory is even more questionable. However, the literature suggests that the addition of a very small amount of viscosifier reduces cell damage in microcarrier culture and this is probably worth reinvestigation (Croughan et al. 1989).

\section{Conclusions}

Regenerative medicine promises both to revolutionise clinical practise and to promote significant economic growth. Realisation of this promise requires robust and scalable manufacturing techniques for the larger scale production of fully functional human stem cells for specific 
purposes. The successful bioprocessing of human stem cells is not a trivial exercise. Indeed, expanding human stem cells in culture is currently more of an art than a science so much so that some laboratories can't or don't grow human stem cells at all. In fact it is only now that successful, yet empirical, protocols for expanding human stem cells in bioreactors are starting to appear in the literature (Abranches et al. 2007; Frauenschuh et al. 2007; Oh et al. 2009), few of which deal with any form of systematic optimisation and none consider the engineering aspects in any depth. An attempt has been made here to understand some of these issues and it is important to note that some of the parameters measured were similar to those associated with other adherent cell lines.

From the work described here it is clear that the Cytodex 3 microcarriers were not damaged using either agitator geometry at the minimum speed for microcarrier suspension. Although there were no directly observable dead cells or cell debris, it seems that microcarrier collisions were the most likely cause of reduced maximum cell numbers per microcarrier. In spite of the question marks over the applicability of turbulence theory with respect to the potential for damage to cells because of the low Re number, the current work gave reasonable agreement with earlier work. This leads to the suggestion that a spinner flask impeller should be chosen that, when it is operated at the minimum speed for microcarrier suspension, results in an (estimated) Kolmogorov microscale of turbulence of about $2 / 3$ the microcarrier diameter or larger. The seeding density ought to be just above that required for growth as higher densities may be deleterious. A 1 day delay before the start of agitation is also recommended to allow initial cell attachment to the microcarriers. The best conditions for expansion in spinner flasks of the hMSCs used in this work were 3000 microcarriers $\mathrm{mL}^{-1}$ and a seeding density of 5 cells per microcarrier, using impeller geometry G2 run at the minimum speed for microcarrier suspension, with a 1 day impeller delay. 
Finally, the development of viable, scalable bioprocessing techniques is critical to being able to produce standardised human stem cells for banking, toxicological/metabolic studies and for bringing human cell based therapies to clinic. These challenges are not easy to solve, indeed hMSC microcarrier cultures are clearly governed by a number of important engineering and biological factors most of which are not fully understood. However, the work described here is seen as being an important fundamental step in addressing a key human stem cell bio-processing challenge.

\section{ACKNOWLEDGMENTS}

The authors would like to acknowledge the financial support of the Biotechnology and Biological Sciences Research Council (UK) and Smith and Nephew (York, UK) for their financial support. 


\section{References}

Abranches E, Bekman E, Henrique D, Cabral JMS (2007) Expansion of mouse embryonic stem cells on microcarriers. Biotechnol. Bioeng. 96: 1211-1222.

Allegrucci C, Young LE (2007) Differences between human embryonic stem cell lines. Hum. Reprod. Update. 13: 103-20.

Barker C, Culme-Seymour E, Dalton S, Hayek A, Genbacev O (2011) The year in regenerative medicine. Regen. Med. 6: 21-30.

Butler M (1996) Cell line and culture monitoring. The basics: animal cell culture and technology. IRL Press, pp 33-45.

Cherry RS, Papoutsakis ET (1986) Hydrodynamic effects on cells in agitated tissue culture reactors. Bioproc. Eng. 1: 28-41.

Cherry RS, Papoutsakis ET (1988) Physical mechanisms of cell damage in microcarrier cell culture bioreactors. Biotechnol. Bioeng. 32: 1001-1014.

Croughan MS, Hamel J-F, Wang DIC (1987) Hydrodynamic effects on animal cells grown in microcarrier cultures. Biotechnol. Bioeng. 29: 130-141.

Croughan MS, Hamel J-F, Wang DIC (1988) Effect of microcarrier concentration in animal cell culture. Biotechnol. Bioeng. 32: 975-982.

Croughan MS, Sayre ES and Wang DIC (1989) Viscous reduction of turbulent damage in animal cell culture, Biotechnol. Bioeng. 33: 862 -872. 
Frauenschuh S, Reichmann E, Ibold Y, Goetz PM, Sittinger M, Ringe J (2007) A microcarrierbased cultivation system for expansion of primary mesenchymal stem cells. Biotechnol. Prog. 23: 187-193.

GE Healthcare (2009) Cytodex ${ }^{\mathrm{TM}}$ Surface Microcarriers. Data file 18-1060-61 AF.

Hu WS, Meier J, Wang DIC (1985) A mechanistic analysis of the inoculum requirement for the cultivation of mammalian cells on microcarriers. Biotechnol. Bioeng. 27: 585-595.

Ibrahim S, Nienow AW (2004) Suspension of microcarriers for cell culture with axial flow impellers. Chem. Eng. Res. Des. 82: 1082-1088.

Kresta SM and Brodkey RS (2004) Turbulence in mixing applications. In Paul EL, Atiemo-Obeng VA, Kresta SM (Eds), Handbook of Industrial Mixing. Wiley- Interscience, Hoboken, NJ, USA, Ch 2, pp $19-87$.

Kumar N, Gammell P, Meleady P, Henry M, Clynes M (2008) Differential protein expression following low temperature culture of suspension cho-k1 cells. BMC Biotechnology. 8: 42.

Schutt C, Furll B, Stelter F, Jack RS, Witt S (1997) CHO transfectants produce large amounts of recombinant protein in suspension culture. J. Immunol. Methods. 204: 99-102.

Nagata S (1975) Mixing; principles and applications, Kodansha, Tokyo.

Nienow AW, Conti R (1978) Particle abrasion at high solids concentration in stirred vessels. Chem. Eng. Sci. 33: 1077-1086. 
Nienow AW (1997a) The suspension of solid particles, in "Mixing in the Process Industries", 2nd Edition (paperback revision), (Editors, Harnby N, Edwards MF, Nienow), Butterworth Heinemann, London, Chapter 16, (1997), pp. 364-393.

Nienow AW (1997b) The mixer as a reactor - liquid/solid systems, in "Mixing in the Process Industries", 2nd Edition (paperback revision), (Eds, Harnby N, Edwards MF, Nienow), Butterworth Heinemann, London, Chapter 17, (1997), pp.394-411

Nienow AW (2006) Reactor engineering in large scale animal cell culture. Cytotechnol. 50: 9 33.

Nienow AW (2010) Impeller selection: animal cell culture, in "Encyclopedia of Industrial Biotechnology”, John Wiley \& Sons, Inc., Hoboken, NJ, USA, Vol. 5, pp 2959-2971.

Oh SKW, Nienow AW, Al-Rubeai M, Emery AN (1992) Further studies of the culture of mouse hybridomas in an agitated bioreactor with and without continuous sparging. J. Biotechnol. 22: 245-270.

Oh SK, Chen AK, Mok Y, Chen X, Lim UM, Chin A, Choo AB, Reuveny S (2009) Long-term microcarrier suspension cultures of human embryonic stem cells. Stem Cell Res. 2: 219-230.

Paul EL, Atiemo-Obeng VA, Kresta SM (2004) Handbook of industrial mixing. WileyInterscience, Hoboken, NJ, USA. 
Rushton JH, Costich EW, Everett HJ (1950) Power characteristics of mixing impellers, Chem. Eng. Prog. 46: 467 -471.

Schutt C, Furll B, Stelter F, Jack RS, Witt S (1997) CHO transfectants produce large amounts of recombinant protein in suspension culture. J. Immunol. Methods. 204: 99-102.

Sucosky P, Osorio DF, Brown JB, Neitzel GP (2004) Fluid mechanics of a spinner-flask bioreactor. Biotechnol. Bioeng. 85: 34-46.

Thomas CR, Zhang Z (1998) The effect of hydrodynamics on biological material, Adv. Bioprocess Eng. (Eds. Galindo E, Ramirez OT) Kluwer, London, pp 137 - 169.

Thomson H (2007) Bioprocessing of embryonic stem cells for drug discovery. Trends Biotechnol. 25:224-230.

Venkat RV, Stock LR, Chalmers JJ (1996) Study of hydrodynamic in microcarrier culture spinner vessels: a Particle Tracking Velocimetry approach. Biotechnol. Bioeng. 49: 456-466. 
Figures

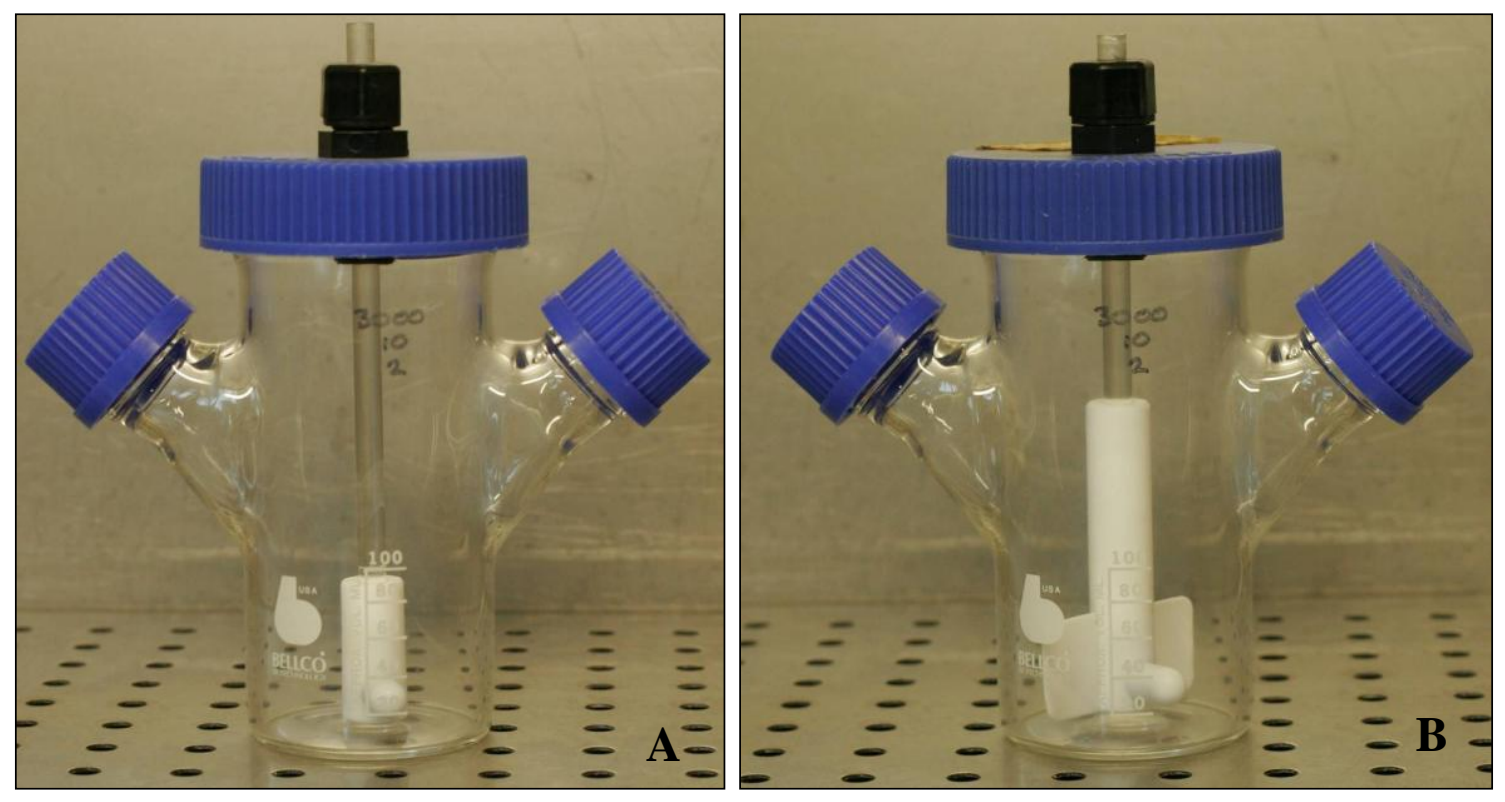

Figure 1. 


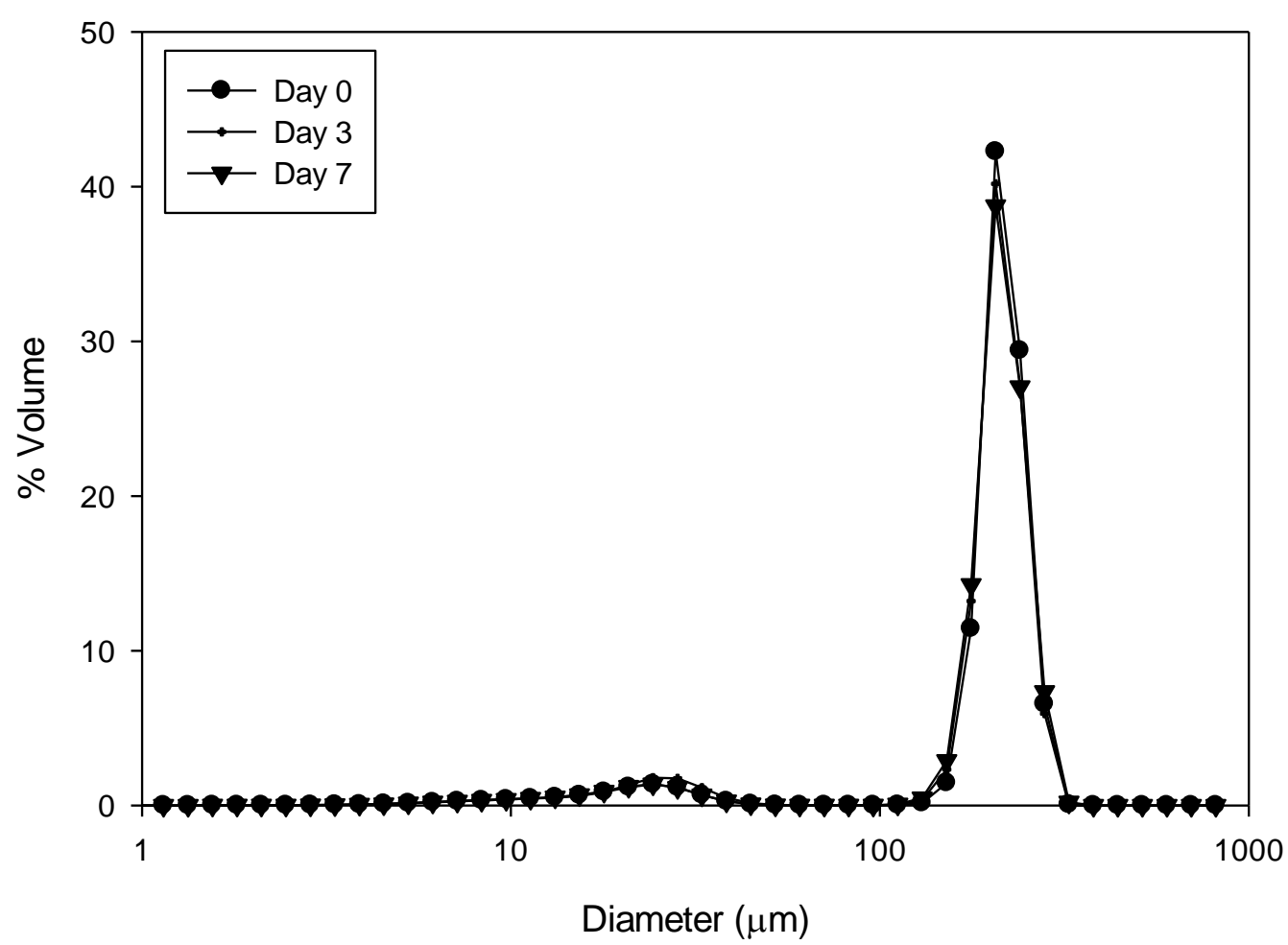

Figure 2. 


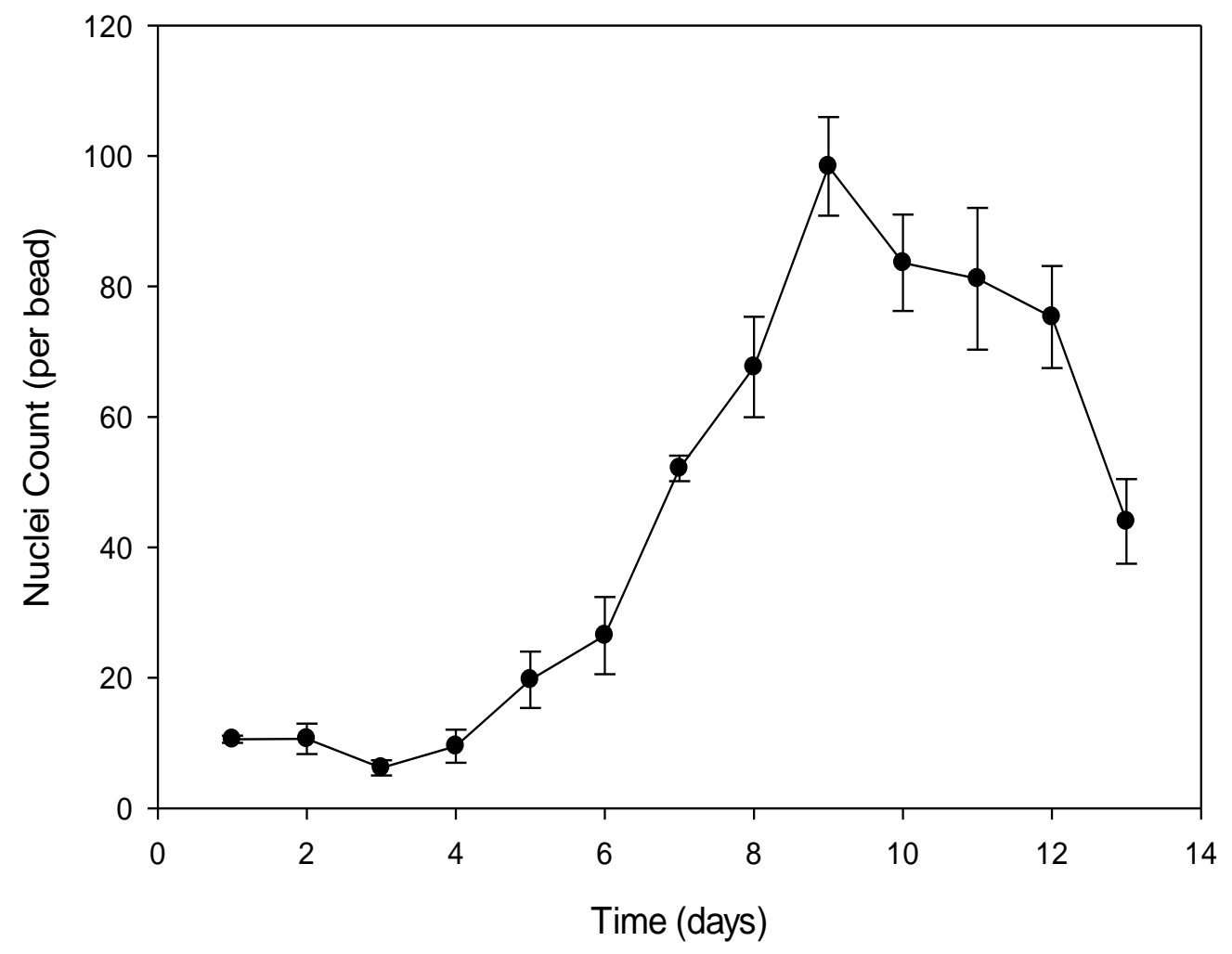

Figure 3. 


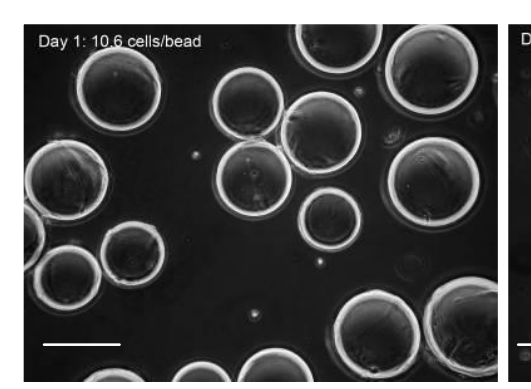

a)

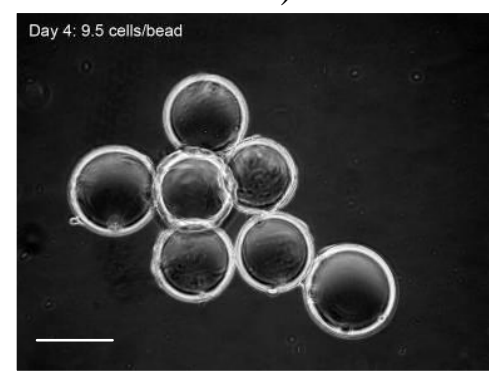

d)

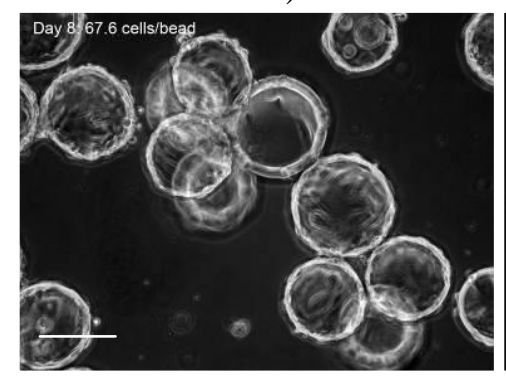

g)

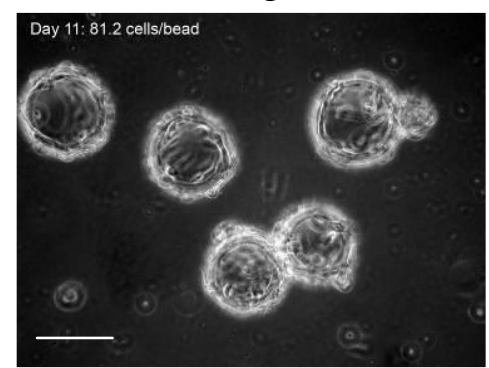

j)

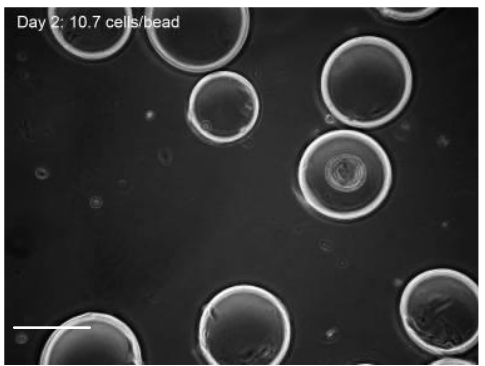

b)

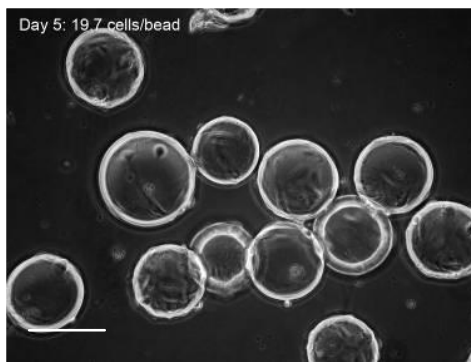

e)

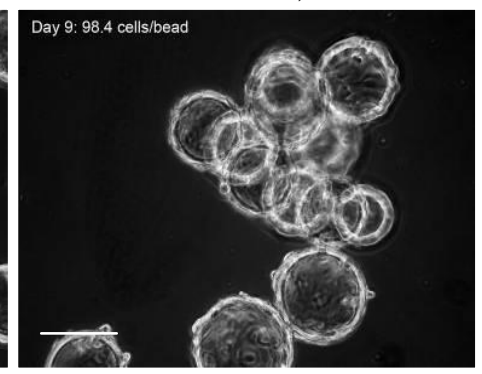

h)

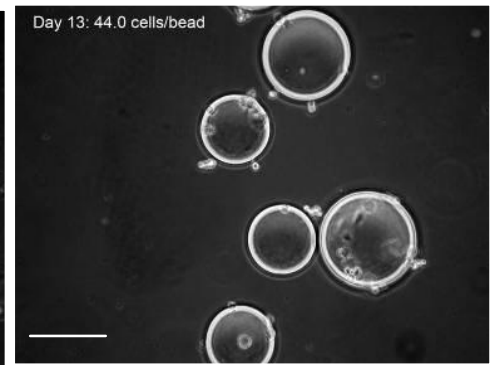

k)

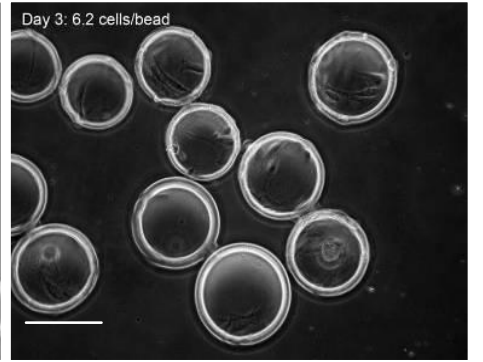

c)

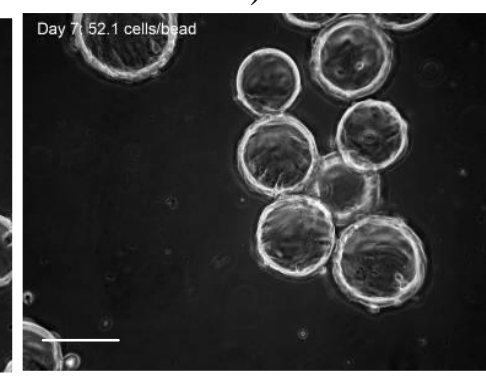

f)

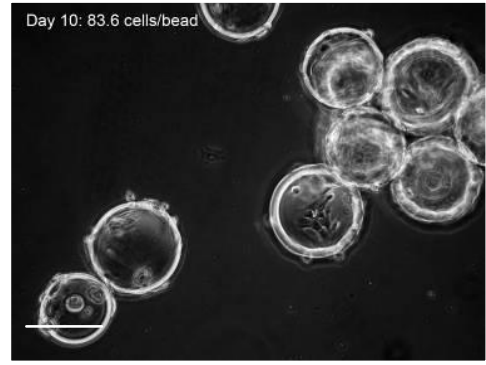

i)

Figure 4. 


\section{Tables}

$\begin{array}{cccl}\begin{array}{c}\text { Impeller diameter } \\ (\mathrm{mm})\end{array} & \begin{array}{c}\text { Speed } \\ (\mathrm{rpm})\end{array} & \begin{array}{c}\text { Reynolds } \\ \text { number }\end{array} & \text { Source } \\ & \text { NA } & 2300-11500 & \begin{array}{l}\text { Cherry and Papoutsakis (1986) } \\ \text { NA }\end{array} \\ 53 & 35 & 2480 & \text { Croughan } \text { et al. }(1988) \\ 78 & 35 & 3550 & \text { Croughan } \text { et al. }(1988) \\ 60 & 45 & 2700 & \text { Cherry and Papoutsakis (1988) } \\ 40 & 70 & 1870 & \text { Cherry and Papoutsakis (1988) } \\ \text { NA } & \text { NA } & 1758 & \text { Sucosky } \text { et al. }(2004) \\ 45 & 50 & 1690 & \text { This work } \\ 55 & 30 & 1510 & \text { This work }\end{array}$

Table 1. 


\begin{tabular}{|c|c|c|c|c|c|c|c|}
\hline Impeller & $\begin{array}{c}\text { Diameter } \\
D \\
(\mathrm{~mm})\end{array}$ & $\begin{array}{l}\text { Height } \\
(\mathrm{mm})\end{array}$ & $\begin{array}{c}\text { Swept } \\
\text { volume } \\
\times 10^{5} \\
\left(\mathrm{~m}^{3}\right)\end{array}$ & $\begin{array}{c}\text { Impeller } \\
\text { speed } N \\
(\mathrm{rps})\end{array}$ & $\begin{array}{c}\text { Power } \\
\text { number } \\
\text { Po }\end{array}$ & $\begin{array}{c}\text { Specific } \\
\text { energy } \\
\text { dissipation } \\
\text { rate } \varepsilon_{T} \\
\times 10^{-4} \\
\left(\mathrm{~W} \mathrm{~kg}{ }^{-1}\right)\end{array}$ & $\begin{array}{c}\text { Estimated } \\
\text { microscale } \\
\text { of } \\
\text { turbulence } \\
\lambda_{\mathrm{K}} \\
(\mu \mathrm{m})\end{array}$ \\
\hline G1 & 45 & 10 & 1.59 & 0.83 & 0.5 & 34 & 131 \\
\hline G2 & 55 & 30 & 7.13 & 0.5 & 1.0 & 8.8 & 183 \\
\hline
\end{tabular}

Table 2 


\begin{tabular}{|c|c|c|c|c|c|}
\hline $\begin{array}{l}\text { Microcarrier } \\
\text { concentration } \\
\left(\text { microcarrier } \mathrm{mL}^{-1}\right)\end{array}$ & $\begin{array}{l}\text { Seeding density } \\
\text { (cells per } \\
\text { microcarrier) }\end{array}$ & $\begin{array}{c}1 \\
\text { day } \\
\text { delay }\end{array}$ & $\begin{array}{l}\text { Mean maximum } \\
\text { cell number per } \\
\text { microcarrier }\end{array}$ & $\begin{array}{l}\text { Expansion } \\
\text { factor }\end{array}$ & $\begin{array}{c}\text { Mean } \\
\text { maximum } \\
\text { cell number } \\
\mathrm{mL}^{-1} \\
\times 10^{-5}\end{array}$ \\
\hline \multicolumn{6}{|c|}{ Impeller G1 (A) } \\
\hline 3000 & 5 & $\times$ & $56 \pm 1$ & 11 & 1.7 \\
\hline 3000 & 5 & $\sqrt{ }$ & $54 \pm 5$ & 11 & 1.6 \\
\hline 3000 & 10 & $x$ & $21 \pm 5$ & 2 & 0.6 \\
\hline 3000 & 10 & $\sqrt{ }$ & $80 \pm 7$ & 8 & 2.4 \\
\hline 7500 & 5 & $x$ & $26 \pm 5$ & 5 & 2.0 \\
\hline 7500 & 5 & $\sqrt{ }$ & $50 \pm 3$ & 10 & 3.8 \\
\hline 7500 & 10 & $x$ & $18 \pm 1$ & 2 & 1.4 \\
\hline 7500 & 10 & $\sqrt{ }$ & $39 \pm 1$ & 4 & 2.9 \\
\hline \multicolumn{6}{|c|}{ Impeller G2 (B) } \\
\hline 3000 & 5 & $\times$ & $64 \pm 14$ & 13 & 1.9 \\
\hline 3000 & 5 & $\sqrt{ }$ & $101 \pm 11$ & 20 & 3.0 \\
\hline 3000 & 10 & $x$ & $22 \pm 7$ & 2 & 0.7 \\
\hline 3000 & 10 & $\sqrt{ }$ & $64 \pm 3$ & 6 & 1.9 \\
\hline 7500 & 5 & $x$ & $51 \pm 10$ & 10 & 3.8 \\
\hline 7500 & 5 & $\sqrt{ }$ & $48 \pm 1$ & 10 & 3.6 \\
\hline 7500 & 10 & $\times$ & $34 \pm 3$ & 3 & 2.6 \\
\hline 7500 & 10 & $\sqrt{ }$ & $43 \pm 2$ & 4 & 3.2 \\
\hline
\end{tabular}

Table 3. 


\section{Figure and Table Captions}

Figure 1. The two different impeller geometries that were used in the $100 \mathrm{ml}$ (working volume) spinner flasks: the first, G1 (A) consisted only of a magnetically driven horizontally suspended flea (length $45 \mathrm{~mm}$; diameter 10mm), whilst the second, G2 (B), was made up from the same suspended flea with an additional vertical Teflon paddle (30 $\mathrm{mm}$ high; length $55 \mathrm{~mm})$.

Figure 2. Particle size distribution for Cytodex 3 microcarriers held at $\mathrm{N}_{\mathrm{JS}}$ (without cells), in this case $50 \mathrm{rpm}$ (G1 i.e. flask A from Figure 1) and at $37^{\circ} \mathrm{C}$ for 0,3 and 7 days in a humidified incubator.

Figure 3. Viable mesenchymal stem cell numbers on Cytodex 3 microcarriers using G1 (i.e. flask A from Figure 1) at $\mathrm{N}_{\mathrm{JS}}, 3000$ microcarriers $\mathrm{mL}^{-1}, 5$ cells/microcarrier with a 1 day impeller delay (i.e. no agitation initially) over 13 days.

Figure 4. Mesenchymal stem cell growth on Cytodex 3 microcarriers (size bar $=200 \mu \mathrm{m}$ ) using G1 (i.e. flask A from Figure 1) at $\mathrm{N}_{\mathrm{JS}}, 3000$ microcarriers $\mathrm{mL}^{-1}, 5$ cells/microcarrier with a 1 day impeller delay (i.e. no agitation initially) over 13 days. a) Day 1, 10.6 cells/bead; b) day 2, 10.7 cells/bead; c) day 3, 6.2 cells/bead; d) day 4, 9.5 cells/bead; e) day 5, 19.7 cells/bead; f) day 7, 52.1 cells/bead; g) day 8, 67.6 cells/bead; h) day 9, 98.4 cells/bead; i) day 10, 83.6 cells/bead; j) day $11,81.2$ cells/bead; day $13,44.0$ cells/bead.

Table 1. Reynolds numbers for both geometries of $100 \mathrm{ml}$ spinner flask G1 (i.e. flask A from Figure 1) and G2 (i.e. flask B from Figure 1) either taken from the reference source or estimated 
assuming water-like suspension properties (kinematic viscosity $10^{-6} \mathrm{~m}^{2} \mathrm{~s}^{-1}$ ). NA: information not available.

Table 2. Calculation of Kolmogorov microscale of turbulence, $\lambda_{K} \mu \mathrm{m}$. Impeller G1 (i.e. flask A from Figure 1) consisted only of a magnetically driven horizontally suspended flea (length 45 mm; diameter 10mm), whilst impeller G2 (i.e. flask B from Figure 2) had an additional vertical Teflon paddle (30 $\mathrm{mm}$ high; length $55 \mathrm{~mm}$ ).

Table 3. Summary of the mean maximum number of cells achieved per Cytodex 3 microcarrier under various conditions using both types of $100 \mathrm{ml}$ spinner flasks G1 (flask A from Figure 1) and G2 (i.e. flask B from Figure 1). 